\title{
O Brasil com axé: candomblé e umbanda no mercado religioso
}

\author{
REGINALDO PRANDI
}

\section{As religiões afro-brasileiras em mudança}

$\mathrm{O}$ CANDOMBLÉ - religião brasileira dos orixás e outras divindades africanas que se constituiu na Bahia no século XIX - e demais modalidades religiosas conhecidas pelas denominações regionais de xangô, em Pernambuco, tambor-de-mina, no Maranhão, e batuque, no Rio Grande do Sul, formavam, até meados do século XX, uma espécie de instituição de resistência cultural, primeiramente dos africanos, e depois dos afro-descendentes, resistência à escravidão e aos mecanismos de dominação da sociedade branca e cristã que marginalizou os negros e os mestiços mesmo após a abolição da escravatura. Eram religiões de preservação do patrimônio étnico dos descendentes dos antigos escravos. Assim foram conhecidas e analisadas por Roger Bastide que, entretanto, já observava a presença de brancos no candomblé no final da década de 1940, antecipando a transformação do candomblé e congêneres em religiões de caráter universal (Bastide, 1945, 1971, 1978). De lá para cá, muita coisa mudou, fazendo dessas religiões organizações de culto desprendidas das amarras étnicas, raciais, geográficas e de classes sociais. Não tardou e foram lançadas no mercado religioso, o que significa competir com outras religiões na disputa por devotos, espaço e legitimidade.

No início do século XX, enquanto os cultos africanos tradicionais eram preservados em seus nascedouros brasileiros, uma nova religião se formava no Rio de Janeiro, a umbanda, síntese dos antigos candomblés banto e de caboclo transplantados da Bahia para o Rio de Janeiro, na passagem do século XIX para o XX, com o espiritismo kardecista, chegado da França no final do século XIX. Rapidamente disseminada por todo o Brasil, a umbanda prometia ser a única grande religião afro-brasileira destinada a se impor como universal e presente em todo o País (Camargo, 1961). E de fato não tardou a se espalhar também por países do Cone Sul e depois mais além (Oro, 1993). Chamada de "a religião brasileira" por excelência, a umbanda juntou o catolicismo branco, a tradição dos orixás da vertente negra, e símbolos, espíritos e rituais de referência indígena, inspirando-se, assim, nas três fontes básicas do Brasil mestiço.

No curso da década de 1960, entretanto, o velho candomblé surgiu como forte competidor da umbanda. Com sua lógica própria e sua capacidade de fornecer ao devoto uma rica e instigante interpretação do mundo, o candomblé foi se espalhando da Bahia para todo o Brasil, seguindo a trilha já aberta pela vertente umbandista. Foi se transformando e se adaptando a novas condições sociais e 
culturais. Religião que agora é de todos, o candomblé enfatiza a idéia de que a competição na sociedade é bem mais aguda do que se podia pensar, que é preciso chegar a níveis de conhecimento mágico e religioso muito mais densos e cifrados para melhor competir em cada instante da vida, que o poder religioso tem amplas possibilidades de se fazer aumentar. Ensina que não há nada a esconder ou reprimir em termos de sentimentos e modos de agir, com relação a si mesmo e com relação aos demais, pois neste mundo podemos ser o que somos, o que gostaríamos de ser e o que os outros gostariam que fôssemos - a um só tempo (Prandi, 1991 e 1996). Como agência de serviços mágicos, que também é, oferece ao não-devoto a possibilidade de encontrar solução para problema não resolvido por outros meios, sem maiores envolvimentos com a religião. Sua magia passou a atender a uma larga clientela, o jogo de búzios e os ebós do candomblé rapidamente se popularizaram, concorrendo com a consulta a caboclos e pretos-velhos da umbanda.

Parcela importante da legitimidade social que a cultura negra do candomblé desfruta hoje foi gestada a partir de uma nova estética formulada pela classe média intelectualizada do Rio de Janeiro e de São Paulo nas décadas de 1960 e 1970, que adotou e valorizou mais do que nunca aspectos negros da cultura baiana, seus artistas e intelectuais. Começava o que chamei de processo de africanização do candomblé (Prandi, 1991), em que o retorno deliberado à tradição significa o reaprendizado da língua, dos ritos e mitos que foram deturpados e perdidos na adversidade da Diáspora; voltar à África não para ser africano, nem para ser negro, mas para recuperar um patrimônio cuja presença no Brasil é agora motivo de orgulho, sabedoria e reconhecimento público, e assim ser o detentor de uma cultura que já é, ao mesmo tempo, negra e brasileira, porque o Brasil já se reconhece no orixá, o Brasil com axé.

Em resumo, ao longo do processo de mudanças mais geral que orientou a constituição das religiões dos deuses africanos no Brasil, o culto aos orixás primeiro misturou-se ao culto dos santos católicos para ser brasileiro, forjando-se o sincretismo; depois apagou elementos negros para ser universal e se inserir na sociedade geral, gestando-se a umbanda; finalmente, retomou origens negras para transformar também o candomblé em religião para todos, iniciando um processo de africanização e dessincretização para alcançar sua autonomia em relação ao catolicismo. Nos tempos atuais, as mudanças pelas quais passam essas religiões são devidas, entre outros motivos, à necessidade da religião se expandir e se enfrentar de modo competitivo com as demais religiões. A maior parte dos atuais seguidores das religiões afro-brasileiras nasceu católica e adotou a religião que professa hoje em idade adulta. Não é diferente para evangélicos e membros de outros credos.

\section{Quantos são os de religião afro-brasileira?}

Segundo o recenseamento de 2000 , apenas $0,3 \%$ da população brasileira adulta declaram-se pertencentes a uma das religiões afro-brasileiras, o que 
corresponde a pouco mais de 470 mil seguidores, embora pesquisas feitas com metodologia mais precisa indicam valores maiores, da ordem de pelo menos o dobro das cifras encontradas pelo censo (Pierucci e Prandi, 1996). Quando se trata das religiões afro-brasileiras, as estatísticas sobre os seguidores costumam oferecem números subestimados, o que se deve às circunstâncias históricas nas quais essas religiões surgiram no século XIX, quando o catolicismo era a única religião tolerada no País, a religião oficial, e a fonte básica de legitimidade social. Para se viver no Brasil, mesmo sendo escravo, e principalmente depois, sendo negro livre, era indispensável, antes de mais nada, ser católico. Por isso, os negros que recriaram no Brasil as religiões africanas dos orixás, voduns e inquices se diziam católicos e se comportavam como tais. Além dos rituais de seu ancestrais, freqüentavam também os ritos católicos. Continuaram sendo e se dizendo católicos, mesmo com o advento da República, no fim do século XIX, quando o catolicismo perdeu a condição de religião oficial e deixou de ser a única religião tolerada no país.

Desde o início as religiões afro-brasileiras se fizeram sincréticas, estabelecendo paralelismos entre divindades africanas e santos católicos, adotando o calendário de festas do catolicismo, valorizando a freqüência aos ritos e sacramentos da Igreja católica. Assim aconteceu com o candomblé da Bahia, o xangô de Pernambuco, o tambor-de-mina do Maranhão, o batuque do Rio Grande do Sul e outras denominações, todas elas arroladas pelo censo do IBGE (Instituto Brasileiro de Geografia e Estatística) sob o nome único e mais conhecido: candomblé. Até recentemente, essas religiões eram proibidas e, por isso, duramente perseguidas por órgãos oficiais. Continuam a sofrer agressões, hoje menos da polícia e mais de seus rivais pentecostais, e seguem sob forte preconceito, o mesmo preconceito que se volta contra os negros, independentemente de religião. Por tudo isso, é muito comum, mesmo atualmente, quando a liberdade de escolha religiosa já faz parte da vida brasileira, muitos seguidores das religiões afro-brasileiras ainda se declararem católicos, embora sempre haja uma boa parte que declara seguir a religião afro-brasileira que de fato professa. Isso faz com que as religiões afro-brasileiras apareçam subestimadas nos censos oficiais do Brasil, em que o quesito religião só pode ser pesquisado de modo superficial.

Com o tempo, as religiões afro-brasileiras tradicionais se espalharam pelo Brasil todo, passando por muitas inovações, mas quanto mais tradicionais os redutos pesquisados, mais os afro-brasileiros continuam se declarando, e se sentindo, católicos. Mais perto da tradição, mais católico. Um mapeamento dos afro-brasileiros declarados nas diferentes regiões mostra isso muito bem: eles são em número relativamente pequeno no Nordeste, região em que a religião afrobrasileira tradicional se formou, o que pode parecer paradoxal, e em número bem maior nas regiões em que se instalou mais recentemente, já no século XX, e onde a mudança religiosa no campo afro-brasileiro tem se mostrado mais vigorosa, casos do Sudeste e do Sul. Até hoje o catolicismo é uma máscara usada 
pelas religiões afro-brasileiras, máscara que, evidentemente, as esconde também dos recenseamentos.

Por sua vez, a umbanda é igualmente problemática quando se trata de quantificar seus seguidores. No início, a nova religião denominou-se espiritismo de umbanda, e não é incomum, ainda atualmente, os umbandistas se chamarem de espíritas, quando não de católicos. A umbanda conservou do candomblé o sincretismo católico: mais que isto, assimilou preces, devoções e valores católicos que não fazem parte do universo do candomblé. Na sua constituição interna, a umbanda é muito mais sincrética que o candomblé.

Voltemos à questão dos números. $\mathrm{O}$ crescimento das cifras de adeptos declarados do candomblé e da umbanda, de um censo para outro, poderia ser atribuído a duas fontes de variação. Primeiro, os números refletiriam um aumento real no número de seguidores; segundo, seria conseqüência do fato de que a expansão da liberdade de crença no Brasil faria com que mais adeptos do candomblé e umbanda, que antes se escondiam sob a rubrica de católicos e espíritas, se declarassem de religião afro-brasileira. Os números crescentes mostrariam que a religião cresce porque tem mais fiéis ou porque uma parcela maior dos antigos seguidores passa a se declarar abertamente.

Feitas essas ressalvas, o que os dados disponíveis nos mostram é que o conjunto das religiões afro-brasileiras vem perdendo adeptos nos últimos vinte anos, os números são decrescentes. Considerando que, atualmente, são menos imperativas as razões que têm levado os afro-brasileiros a se declararem católicos ou espíritas, a queda recentemente observada só pode ser real, e pode até mesmo ser maior, uma vez que em censos anteriores as taxas de "escondidos" podiam ser maiores que as de agora.

De todo modo, o pequeno contingente de afro-brasileiros declarados, em 1980, representava apenas 0,6\% da população brasileira residente. Em 1991, eles eram 0,4\% e agora, em 2000, são 0,3\%. De 1980 a 1991, os afro-brasileiros perderam trinta mil seguidores declarados, perda que na década seguinte subiu para 71 mil. Ou seja, o segmento das religiões afro-brasileiras está em declínio.

Podem ser muitas as razões do declínio afro-brasileiro, mas certamente elas estão associadas às novas condições da expansão das religiões no Brasil no contexto do mercado religioso. A oferta de serviços que a religião é capaz de propiciar aos consumidores religiosos e as estratégias de acessar os consumidores e criar novas necessidades religiosas impõem mudanças que nem sempre religiões mais ajustadas à tradição conseguem assumir. É preciso, sobretudo, enfrentar-se com os concorrentes, atualizar-se. Para religiões antigas, podem ocorrer mudanças que mobilizam apenas um setor dos líderes e devotos, como, por exemplo, ontem, a fração das Comunidades Eclesiais de Base e, hoje, a parcela da Renovação Carismática do catolicismo (Prandi, 1997). Isso vale para os grandes grupos religiosos. No caso dos evangélicos, avançam os renovados pentecostais, mas declinam algumas das denominações históricas. 
Certamente, o sincretismo católico, que por quase um século serviu de guarida aos afro-brasileiros, não deve mais lhes ser tão confortável. Quando o próprio catolicismo está em declínio, a âncora sincrética católica pode estar pesando desfavoravelmente para os afro-brasileiros, fazendo-os naufragar. Por outro lado, é sabido como muitas igrejas neopentecostais têm crescido às custas das religiões afro-brasileiras, sendo que para uma de suas mais bem-sucedidas versões, a Igreja Universal do Reino de Deus, o ataque sem trégua ao candomblé e à umbanda e a seus deuses e entidades é constitutivo de sua própria identidade (Mariano, 1999).

Mas se o conjunto dos afro-brasileiros está em declínio, essa queda é devida ao segmento umbandista, que cai, enquanto sobe o candomblé. Os censos de 1991 e 2000 fornecem dados separados para a umbanda e o candomblé, sendo que a classificação candomblé reúne as chamadas religiões afro-brasileiras tradicionais (candomblé, xangô, tambor-de-mina, batuque). Como, pelo menos desde a década de 1950, a umbanda tem sido majoritária no conjunto afro-brasileiro, seu peso maior reflete diretamente na estatística geral do conjunto, indicando declínio.

Mas a participação relativa do candomblé tem aumentado. Em 1991, o candomblé já tinha conquistado $16,5 \%$ dos seguidores das diferentes denominações de origem africana. Em 2000, esse número passou a $24,4 \%$. O candomblé cresceu para dentro e para fora do universo afro-brasileiro. Seus seguidores declarados eram cerca de 107 mil em 1991 e quase 140 mil em 2000, o que representa um crescimento de $31,3 \%$ num período em que a população brasileira cresceu $15,7 \%$. Sem dúvida, um belo crescimento. Por outro lado, a umbanda, que contava com aproximadamente 542 mil devotos declarados em 1991, viu seu contingente reduzido para 432 mil em 2000. Uma perda enorme, de 20,2\%. E porque o peso da umbanda é maior que o do candomblé na composição das religiões afro-brasileiras, registrou-se para este conjunto nada mais nada menos que um declínio de $11,9 \%$ numa só década. Na década anterior, fato para o qual Ricardo Mariano chamou a devida atenção (Mariano, 2001), as religiões afrobrasileiras já tinham sofrido uma perda de $4,5 \%$, declínio que não somente se confirmou como se agravou na década seguinte. O conjunto encolheu, mas o candomblé cresceu.

\section{Sincretismo, magia e o enfrentamento com pentecostais}

Em seu processo de transformação em religião universal, isto é, religião que se oferece para todos, o candomblé conheceu o que chamamos de movimento de africanização, que implica certas reformas de orientação fortemente intelectual, como o reaprendizado das línguas africanas esquecidas ao longo de um século, a recuperação da mitologia dos deuses africanos, que em parte também se perdeu nesses anos todos de Brasil, e a restauração de cerimoniais africanos (Prandi, 1991 e 2000). Um elemento importante do movimento de africanização do can- 
domblé e sua constituição como religião autônoma inserida no mercado religioso é o processo de dessincretização, com o abandono de símbolos, práticas e crenças de origem católica. É a descatolização do candomblé, que se descentra do catolicismo e se assume como religião autônoma.

Esse processo de africanização, evidentemente, é muito desigual e depende das diferentes situações com que se depara aqui e ali. Podemos, contudo, afirmar com segurança que o candomblé que mais se espalha pelo Brasil, o que mais cresce, é esse que vai cada vez mais deixando de lado as ligações com o catolicismo. Um seguidor desse candomblé pode, se quiser, freqüentar ritos da igreja católica, mas essa participação já não será mais vista como parte do preceito obrigatório a que estavam sujeitos os membros dos candomblés mais antigos; já não é mais um dever ritual. Não é mais necessário mostrar-se católico para poder louvar os deuses africanos, assim como não é mais necessário ser católico para ser brasileiro.

Um seguidor da umbanda está longe dessas preocupações. Ao contrário, em vez de fortalecer sua identidade religiosa, uma aspiração muito corrente entre os umbandistas é a de se iniciarem também no candomblé. Muitos o fazem e entre esses não são poucos os que acabam abandonando a umbanda definitivamente para se dedicar aos orixás segundo o rito do candomblé. Assim se enfraquece a autonomia umbandista. Nos ritos da umbanda, as preces católicas e a invocação de Jesus, Maria e santos da igreja nas letras dos cantos sagrados continuam indispensáveis. Num hipotético processo de dessincretização da umbanda, grande parte de seu hinário teria que ser abandonada, pois as referências às crenças católicas são muito explícitas.

Umbanda e candomblé são religiões mágicas. Ambas pressupõem o conhecimento e o uso de forças sobrenaturais para intervenção neste mundo, o que privilegia o rito e valoriza o segredo iniciático. Além do sacerdócio religioso, a magia é quase que uma atividade profissional paralela de pais e mães-de-santo, voltada para uma clientela sem compromisso religioso (Pierucci, 2001). Nesses termos, o candomblé é visto dentro do próprio segmento afro-brasileiro como fonte de maior poder mágico que a umbanda, o que atrai para o seio do candomblé muitos umbandistas.

Para o candomblé, que está mais perto do pensamento africano que a umbanda, o bem e o mal não se separam, não são campos distintos. A umbanda, porém, quando se formou, se imaginou também como religião ética, capaz de fazer a distinção entre o bem e o mal, à moda ocidental, cristã. Mas acabou criando para si uma armadilha. Separou o campo do bem do campo do mal. Povoou o primeiro com seus guias de caridade, os caboclos, pretos-velhos e outros espíritos bons, à moda kardecista. Para controlar o segundo, arregimentou um panteão de exus-espíritos e pombagiras, entidades que não se acanham em trabalhar para o mal quando o mal é considerado necessário (Prandi, 200la). Ficou dividida entre dois campos éticos opostos, “entre a cruz e a encruzilhada”, na feliz expressão de Lísias Nogueira Negrão (1996). 
Tratado durante muito tempo com discrição e segredo, o culto dos exus e pombagiras, identificados erroneamente como figuras diabólicas, veio recentemente a ocupar na umbanda lugar aberto e de realce (Prandi, 1996, cap. 4 e 2001). Era tudo de que precisava um certo pentecostalismo: agora o diabo estava ali bem à mão, nos terreiros adversários, visível e palpável, pronto para ser humilhado e vencido. O neopentecostalismo leva ao pé da letra a idéia de que o diabo está entre nós, incitando seus seguidores a divisá-lo nos transes rituais dos terreiros de candomblé e umbanda. Pastores da Igreja Universal do Reino de Deus, em cerimônias fartamente veiculadas pela televisão, submetem desertores da umbanda e do candomblé, em estado de transe, a rituais de exorcismo, que têm por fim humilhar e escorraçar as entidades espirituais afro-brasileiras incorporadas, que eles consideram manifestações do demônio (Mariano, 1999).

A umbanda e o candomblé, cada qual a seu modo, são bastante valorizados no mercado de serviços mágicos e sempre foi grande a sua clientela, mas ambos enfrentam hoje a concorrência de incontáveis agências de serviços mágicos e esotéricos de todo tipo e origem, sem falar de outras religiões, que inclusive se apropriam de suas técnicas, sobretudo as oraculares. Concorrem entre si e concorrem com os outros. Por fim, foram deixados em paz pela polícia (quase sempre), mas ganharam inimigos muito mais decididos e dispostos a expulsá-los do cenário religioso, contendores que fazem da perseguição às crenças afro-brasileiras um ato de fé, o que se pode testemunhar tanto no recinto fechado dos templos como no ilimitado e público espaço da televisão e do rádio. Não foi um ato isolado e gratuito o discurso do pastor fluminense Samuel Gonçalves, da Assembléia de Deus, um dos apoiadores do candidato evangélico Anthony Garotinho à Presidência da República, em que afirmou que uma das "três maldições" do Brasil é a religião africana (Folha de S. Paulo, 30/7/2002, p. A6).

\section{Organização e concorrência}

Candomblé e umbanda são religiões de pequenos grupos que se congregam em torno de uma mãe ou pai-de-santo, denominando-se terreiro também cada um desses grupos. Embora se cultivem relações protocolares de parentesco iniciático entre terreiros, cada um deles é autônomo e auto-suficiente, e não há organização institucional eficaz alguma que os unifique ou que permita uma ordenação mínima capaz de estabelecer planos e estratégias comuns na relação da religião afro-brasileira com as outras religiões e o resto da sociedade. As federações de umbanda e candomblé, que supostamente uniriam os terreiros, não funcionam, pois não há autoridade acima do pai ou da mãe-de-santo (Concone e Negrão, 1987). Além disso, os terreiros competem fortemente entre si e os laços de solidariedade entre os diferentes grupos são frágeis e circunstanciais. Não há organização empresarial e não se dispõe de canais eletrônicos de comunicação. Sobretudo, nem o candomblé em suas diferentes denominações nem a umbanda têm quem fale por eles, muito menos quem os defenda. Muito dife- 
rente das modernas organizações empresariais das igrejas evangélicas, que usam de técnicas modernas de marketing, que treinam seus pastores-executivos para a expansão e a prosperidade material das igrejas, que contam com canais próprios e alugados de televisão e rádio, e com representação aguerrida nos legislativos municipais, estaduais e federal. Mais que isso, a derrota das religiões afro-brasileiras é item explícito do planejamento expansionista pentecostal: há igrejas evangélicas em que o ataque às religiões afro-brasileiras e a conquista de seus seguidores são práticas exercidas com regularidade e justificadas teologicamente. Por exemplo, na prática expansiva de uma das mais dinâmicas igrejas neopentecostais, fazer fechar o maior número de terreiros de umbanda e candomblé existentes na área em que se instala um novo templo é meta que o pastor tem que cumprir.

Grande parte da fraqueza das religiões afro-brasileiras advém de sua própria constituição como reunião não organizada e dispersa de grupos pequenos e quase domésticos, que são os terreiros. Num passado recente, entre as décadas de 1950 e 1970, as religiões de conversão se caracterizavam pela formação de pequenas comunidades, em que todos se conheciam e se relacionavam. A religião recriava simbolicamente relações sociais comunitárias que o avanço da industrialização e da urbanização ia deixando de lado. Tanto no terreiro afro-brasileiro como na igreja evangélica, o adepto se sentia parte de um pequeno e bem definido grupo. Ao contrário disso, a religião típica da década de 1980 em diante é uma religião de massa. As reuniões religiosas são realizadas em grandes templos, situados preferencialmente nos lugares de maior fluxo de pessoas, com grande visibilidade, que funcionam o tempo todo - algumas 24 horas - e que reúnem adeptos vindos de todos os lugares da cidade, adeptos que podem freqüentar a cada dia um templo localizado em lugar diferente. Os crentes seguem a religião, mas já não necessariamente se conhecem. O culto também é oferecido dia e noite no rádio e na televisão e o acesso ao discurso religioso é sempre imediato, fácil. Os pastores são treinados para um mesmo tipo de pregação uniforme e imediatista. No catolicismo carismático, por sua vez, a constituição dos pequenos grupos de oração teve que se calçar na criação dos grandes espetáculos de massa das missas dançantes celebradas pelos padres cantores (Souza, 2001). Nesses vinte anos, mudou muito a forma como a religião é oferecida pelos mais bem-sucedidos grupos religiosos. São mudanças a que o candomblé e a umbanda não estão afeitos. Não são capazes de se massificar, mesmo porque a vida religiosa de um afro-brasileiro se pauta principalmente pelo desempenho de papéis sacerdotais dentro de um grupo de características eminentemente familiares. Não é à toa que o grupo de culto é chamado de família-de-santo. Mais que isso: as cerimônias secretas das obrigações e sacrifícios não são abertas sequer a todos os membros de um terreiro, havendo sempre uma seleção baseada nos níveis iniciáticos, não sendo concebível a sua exposição a todos, muito menos sua divulgação por meio televisivo.

Além de se constituírem em pequenas unidades autônomas, reunindo, em geral, não mais que cinqüenta membros, os terreiros de candomblé e umbanda 
usualmente desaparecem com o falecimento da mãe ou pai-de-santo, tanto pelas disputas de sucessão como pelo fato bastante recorrente de que os herdeiros civis da propriedade e demais bens materiais do terreiro, tudo propriedade particular do finado chefe, não se interessam pela continuidade da comunidade religiosa. A não ser em uma dúzia de casas que se transformaram em emblemas de importância regional ou mesmo nacional para a religião, dificilmente um terreiro sobrevive a seu fundador. Tudo sempre começa de novo, pouco se acumula.

Fragmentada em pequenos grupos, fragilizada pela ausência de algum tipo de organização ampla, tendo que carregar o peso do preconceito racial que se transfere do negro para a cultura negra, a religião dos orixás tem poucas chances de se sair melhor na competição - desigual - com outras religiões. Silenciosamente, assistimos hoje a um verdadeiro massacre das religiões afro-brasileiras. Sem um projeto novo de expansão e de reorientação num quadro religioso que se tornou extremamente complexo e competitivo, a umbanda talvez tenha menos recursos que o candomblé para enfrentar a nova conjuntura. Os dados dos censos mostram que é da umbanda que vem o encolhimento demográfico do segmento religioso afro-brasileiro, e o vigor do novo candomblé não tem sido suficiente para compensar as perdas. Nem seus líderes, em grande parte pouco escolarizados, têm sabido como reagir ou como se organizar, mais preocupados que estão em garantir o funcionamento de seus terreiros. A umbanda tem menos de cem anos de idade e parece não conseguir se adaptar às novas demandas que a sociedade apresenta. Já o candomblé, que é pelo menos um século mais antigo que a umbanda, porém renovado pelas mutações que vem sofrendo em sua expansão, tem se mostrado mais ágil para se adequar aos novos tempos. É mais uma demonstração de que a religião que não muda morre.

De todo modo, a importância cultural da umbanda, do candomblé, do xangô, do tambor-de-mina, do batuque e outras denominações menores no cenário cultural brasileiro tem sido sempre maior que seu alcance demográfico em termos da efetiva filiação de seguidores. Sua contribuição às mais diferentes áreas da cultura brasileira é riquíssima, como acontece também noutros países americanos em que se constituíram religiões de origem negro-africana. Mas, se se confirma que o Brasil vem se tornando religiosamente menos afro-brasileiro, a fonte viva de valores, visões de mundo, arranjos estéticos, aromas, sabores, ritmos etc., que são os terreiros de candomblé e umbanda, pode entrar em processo de extinção. Não seria um horizonte promissor para o cultivo da diferença cultural e do pluralismo religioso, cujo alargamento alimentou promessas do final do século XX de mais democracia, diversidade, tolerância e liberdade.

\section{Religião e seguidores em mudança}

Houve tempo em que a mudança de religião representava uma ruptura social e cultural, além de ruptura com a própria biografia, com adesão a novos valores, mudança de visão de mundo, adoção de novos modelos de conduta etc. 
A conversão era um drama, pessoal e familiar, representava uma mudança drástica de vida. O que significa hoje mudar de religião, quando a mudança religiosa parece não comover ninguém, como se mudar de religião fosse já um direito líquido e certo daquele que se transformou numa espécie de consumidor, consumidor religioso, como já se chamou esse converso? Certamente o drama é menos profundo (Pierucci e Prandi, 1996 e Prandi, 2001b).

As mais díspares religiões, assim, surgem nas biografias dos adeptos como alternativas que se pode pôr de lado facilmente, que se pode abandonar a uma primeira experiência de insatisfação ou desafeto, a uma mínima decepção. São inesgotáveis as possibilidades de opção, intensa a competição entre elas, fraca sua capacidade de dar a última palavra. A religião de hoje é a religião da mudança rápida, da lealdade pequena, do compromisso descartável.

Mas não somente o crente muda de um credo para outro, desta para aquela religião. As religiões mudam também e mudam muito rapidamente, muitas vezes suas transformações apontando para um outro público-alvo, visando a uma clientela anteriormente fora do alcance de sua mensagem. É verdade que a religião muda a reboque da sociedade, sobretudo no que diz respeito aos modelos de conduta que prega e valores que propaga, freqüentemente adaptando-se a transformações sociais e culturais já plenamente em curso, num esforço para não perder o trem da história, como tem ocorrido especialmente com a igreja católica. Hoje, provavelmente, muitas das mudanças contemplam não especificamente a sociedade em transformação, mas o conjunto das diferentes religiões que se oferecem como alternativas sacrais, o que significa que a religião muda para poder melhor competir com as outras crenças em termos da adesão de fiéis, e não em razão de se pôr numa posição axiológica mais compatível com os avanços da sociedade, embora isso também possa ser importante e às vezes pressuposto na dinâmica do próprio mercado religioso. Posições anteriormente alcançadas, tanto no plano da filosofia religiosa como no das conseqüências políticas e de orientação na vida cotidiana, que derivam dos valores então assumidos, podem ser completamente abandonadas, com a busca de novos modelos que possam melhor apetrechar aquela religião na concorrência com as demais.

Grupos religiosos, igrejas e denominações cindem-se e se multiplicam, ampliando ainda mais a oferta. Outras apresentam facetas múltiplas, mantendo a unidade institucional, mas sendo capazes de atender a demandas variadas a partir de mensagens diferentes e movimentos particulares, embora gostem de advogar que a diversidade que contemplam e produzem repousa em verdades teológicas únicas. É bastante notória a facilidade com que um adepto do candomblé muda de terreiro, de nação, de grupo religioso, sempre à procura de soluções que acredita poder encontrar fora da comunidade de culto em que se iniciou, trafegando pela enorme variedade de modos de proceder o culto existente no interior do próprio candomblé. Quando não abandona a própria religião para experimentar as mesmas promessas de conforto e felicidade em território pentecostal, 
por exemplo, o que tem sido uma tendência nada desprezível do trânsito religioso brasileiro nas duas últimas décadas.

Evidentemente, os motivos que reforçam a diversidade religiosa não se encontram somente no âmbito dos crentes seguidores, os consumidores de religião, agindo, sobretudo, no interior da própria organização religiosa. Mudanças internas da religião não significam necessariamente perigo para a sua sobrevivência institucional, não implicam apenas separação e ruptura. Ao contrário, quem não muda não sobrevive. Interesses vários podem então ser exercitados com maior liberdade, numa competição interna cujo sucesso se mede não pelos alcances teológicos possíveis, mas pela adesão de crentes. A própria carreira sacerdotal se vê compelida a incorporar novas habilidades, como aquelas até bem pouco mais apropriadas aos homens de negócios e mais marcadamente atributivas de artistas, ginastas e estrelas de TV, entre outras qualidades. Vejam-se, por exemplo, as mudanças profundas que o movimento de Renovação Carismática introduziu no modelo do clérigo católico brasileiro (Prandi, 1997).

Se isso ocorre em religiões unificadas institucionalmente, pode-se imaginar o que acontece em religiões sem unidade administrativa e doutrinária, como as afro-brasileiras, em que cada terreiro tem para com os demais obrigações apenas protocolares, cada um com seu governo independente.

Mesmo em se tratando de religiões severamente consolidadas em termos de organização sacerdotal e obrigações hierárquicas, surgem novos horizontes de mobilidade social baseada na capacidade pessoal de inovação e empreendimento do sacerdote. Nas grandes igrejas, muitas das quais atuando como conglomerados empresarias de acumulação econômica internacional, assim como nas religiões em que a unidade administrativa e sacerdotal é reduzida, fraca ou inexistente, como ocorre em todo o segmento afro-brasileiro, em certas correntes evangélicas e no conjunto das práticas esotéricas, o sucesso do líder religioso, e por conseguinte da sua religião ou modalidade religiosa, depende da sua capacidade de atrair devotos e clientes e gerar renda necessária à expansão daquela denominação.

Tanta oferta, que é crescente, depende de demanda grande e diversificada. Aquilo que se entende por religião deve contemplar necessidades, gostos e expectativas que escapam às velhas definições da religião, surgindo as mais inusitadas formas de acesso ao sagrado e sua manipulação mágica, como ocorre com muita propriedade no vasto e pouco definido universo do esoterismo.

Experimentar novos sentimentos e formas da religião, contudo, não significa necessariamente mudar de religião. Não é preciso sair da religião que se professa para provar da mudança religiosa. Quantas vezes não ouvimos pessoas mais velhas do candomblé reclamar que sua religião não é mais como costumava ser nos seus tempos de juventude? Para os mais velhos, que sentem a mudança como perda, a religião certa é a que não muda. As próprias religiões costumam se apresentar como verdades eternas e imutáveis. "Assim como era no princípio, 
agora e sempre", afirma o Credo católico, oração afirmativa de uma religião em constante transformação.

Tudo isso vale igualmente para o candomblé e a umbanda. Os seguidores dos orixás também acreditam na eternidade das verdades religiosas e na perenidade dos ritos. Sabem que muito se perdeu e se modificou ao longo da história do culto dos orixás no Brasil, quer em razão das adversidades sociais e culturais que enfrentou, a começar da própria escravidão, que por causa da displicência dos sacerdotes mais antigos, que teriam levado para o túmulo muito conhecimento que preferiram não passar adiante. É o que se imagina. Pois bem, esse conhecimento perdido, esquecido, escondido existe em algum lugar, e é imperativo recuperá-lo, para o revigoramento da própria religião e o fortalecimento do poder de seus rituais, é o que se acredita.

A idéia de que é preciso recuperar o mistério perdido ao longo da história da religião no Brasil (língua, rezas, cantigas, oriquis, mitos, odus, ebós, tabus etc.) parte do suposto de que em algum lugar existe sobrevivência ou registro do que se perdeu, que alguém de grande conhecimento é capaz de ensinar a fórmula almejada, que algum processo iniciático em outro templo, nação ritualística, cidade ou país pode resgatar o patrimônio que as gerações anteriores de pais e mães-de-santo, por impedimento sociocultural, egoísmo e desleixo, não souberam transmitir às gerações seguintes. Recobrar segredos guardados é imperativo para restaurar o grande poder mágico da religião. O livro é uma das fontes possíveis, viagens à África e consultas com africanos ou mesmo com velhos sacerdotes brasileiros é outra. Em geral se paga por um segredo guardado, cujo acesso quase sempre depende de submissão a alguma obrigação iniciática. No candomblé, o que é pago é mais valorizado; sem dinheiro não há axé, não há fluxo da força sagrada. Mas a adoção de fórmulas ou elementos recuperados se faz de acordo com a interpretação pessoal, a vontade e o interesse de cada pai ou mãede-santo, e se dá de modo diferente em cada terreiro. Assim, recuperar o passado perdido também significa adaptar, inovar, criar.

Uma das mais profundas mudanças observadas no candomblé nas últimas décadas do século XX foi sua universalização, quando passou de religião étnica a religião de todos, com a incorporação, entre seus seguidores, de novos adeptos de classe média e de origem não africana. Segundo o censo demográfico do IBGE, apenas 16,7\% dos umbandistas se constituíam, no ano 2000, de pessoas que declararam ser de cor preta, cifra que para os dos adeptos do candomblé também foi expressivamente pequena: $22,8 \%$. Surpreendentemente, o censo de 2000 mostrou também que as religiões afro-brasileiras apresentaram a segunda maior média de anos de escolaridade de seus seguidores declarados, ficando atrás apenas do espiritismo kardecista, religião sabidamente de classe média e de seguidores com escolaridade elevada. Para o ano 2000, a média de anos de escolaridade dos membros declarados do candomblé e da umbanda foi de 7,2 anos, quando a média da população total do Brasil era igual a 5,9 anos, a dos espíritas 
kardecistas 9,6 anos, a dos católicos 5,8 anos e a dos evangélicos pentecostais 5,3 anos. São indicadores inequívocos da penetração da classe média branca escolarizada. Certamente esse segmento, que não é a maioria, declara-se afrobrasileiro no quesito de religião do censo com maior freqüência que os pobres e negros.

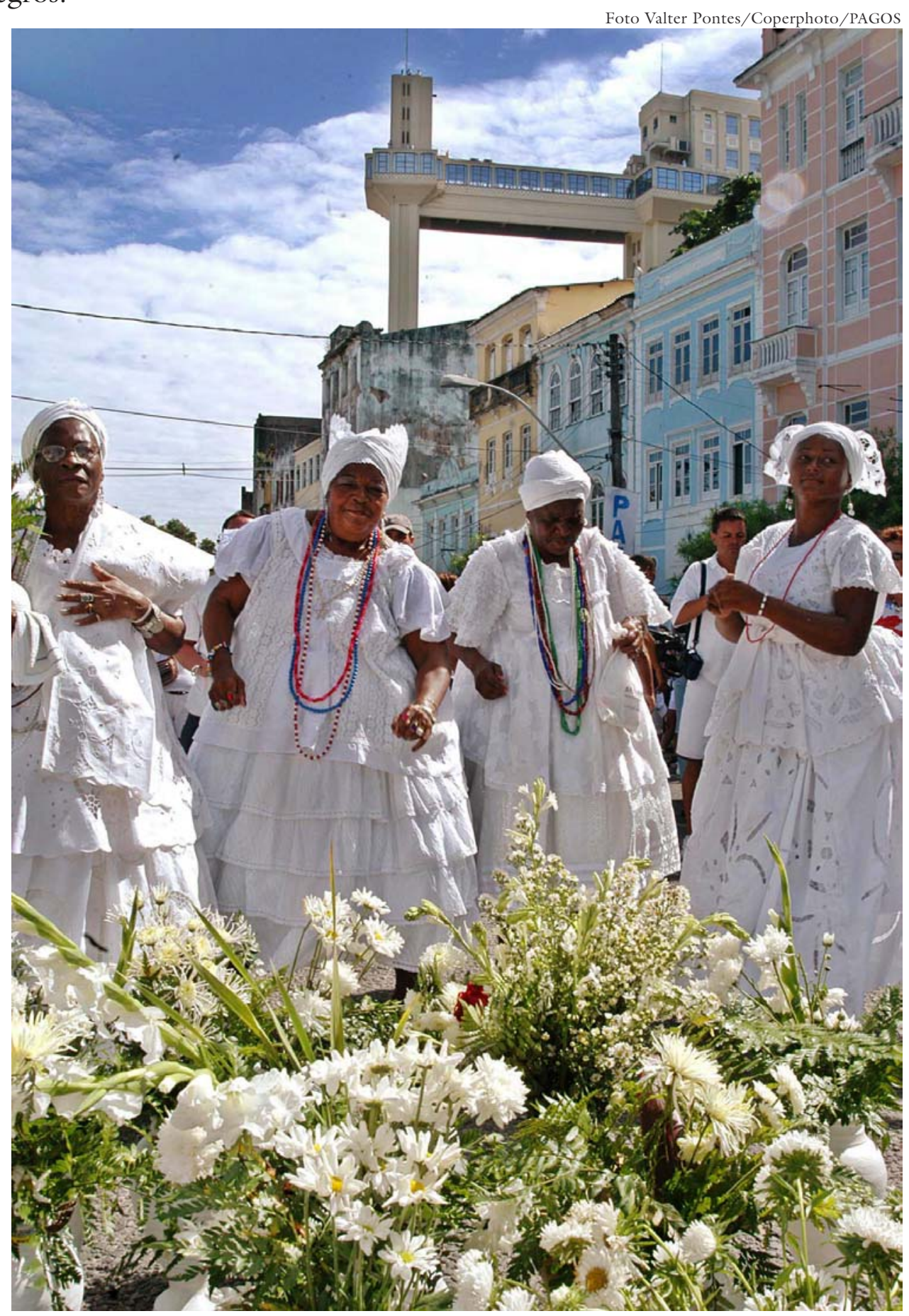

Baianas na Igreja da Conceição da Praia durante a Lavagem do Bonfim em Salvador. 
De fato, a base social do candomblé mudou, e mudou muito. Grande parte, certamente a maioria ainda, é de gente pobre, com muitas dificuldades para arcar com os gastos financeiros impostos pela exuberância e complexidade dos ritos iniciáticos. Mas a classe média branca e escolarizada já está no terreiro, muitas vezes competindo com os negros pobres, que evidentemente, pela sua condição de afro-descendentes, se sentem com freqüência os legítimos donos das tradições dos orixás. Disputam cargos, regalias e posições de mando e de prestígio no intrincado jogo de poder dos terreiros. Levam consigo valores, costumes e aspirações próprios de sua condição social. O hábito de leitura, o gosto pelo estudo, o prazer do consumo descortinam um mundo de novidades a serem buscadas nos livros, nas revistas, na internet, nas atividades universitárias, no mercado de artigos religiosos. No terreiro aprendem o quanto é valorizado o saber religioso. Há tesouros a descobrir em termos da mitologia e dos ritos, segredos perdidos a recuperar. Freqüentemente, vem a decepção: os segredos são de polichinelo, acrescentam pouco ou quase nada ao que se sabia e praticava antes. Pior que isso: mais saber religioso não confere necessariamente mais poder, seja o poder de mando seja o de manipulação mágica. A procura, entretanto, não cessa, outros caminhos são buscados.

Nas religiões dos orixás, cada terreiro tem plena autonomia administrativa, ritual e doutrinária, e tudo depende das decisões pessoais da mãe ou pai-desanto. $\mathrm{O}$ controle social exercido entre terreiros, no conjunto geral do chamado povo-de-santo, se faz por redes informais de comunicação, em que a fofoca ocupa lugar privilegiado (Braga, 1998), sem que a independência do sacerdote-chefe de terreiro, contudo, sofra realmente qualquer limitação eficaz. É costume se dizer que no candomblé "nada pode e tudo pode" e que tabus são para ser quebrados (Augras, 1987). Assim, cada comunidade de culto é livre para experimentar inovações ou retornar a formas anteriores, incorporando práticas que para outros da mesma religião podem não fazer o menor sentido. Cada terreiro exerce o direito de copiar e incorporar novidades, mas costuma dotá-las de outros significados. Pode mudar, afirmando que se mantém na rígida tradição. Terreiros nascem uns dos outros, mas não há dois iguais, mesmo quando se observam os terreiros mais antigos, surgidos da mesma matriz fundante.

Os seguidores são unânimes, entretanto, ao acreditar que o futuro da religião depende tanto da manutenção das velhas tradições, das quais os centenários terreiros da Bahia ainda representam a fonte mais legítima, como da recuperação do conhecimento que se perdeu desde que os velhos fundadores foram arrancados de suas famílias e cidades africanas para serem brutalmente escravizados no Brasil. Pensam o futuro da religião em termos estritamente religiosos e atribuem o progresso ou declínio de seus cultos não em função de planos, políticas e estratégias institucionais, mas à vontade dos orixás. Acreditam que sempre é tempo de recuperar a tradição que não chegou até os dias de hoje, adaptando-a para o presente da religião, pois em algum lugar ainda existe, conforme repetem com muito freqüência, muitos segredos guardados. 
Bibliografia

AUGRAS, Monique. "Quizilas e preceitos: transgressão, reparação e organização dinâmica do mundo". Em MOURA, Carlos Eugênio Marcondes de (org.). Candomblé desvendando identidades. São Paulo, EMW, 1987.

BASTIDE, Roger. O candomblé da Bahia: rito nagô. São Paulo, Nacional, 1978. Nova edição: São Paulo, Companhia da Letras, 2001.

. Imagens do Nordeste místico em preto e branco. Rio de janeiro, O Cruzeiro, 1945.

As religiões africanas no Brasil. São Paulo, Pioneira, 1971.

BRAGA, Júlio. Fuxico de candomblé: estudos afro-brasileiros. Feira de Santana, Universidade Estadual de Feira de Santana, 1998.

CAMARGO, Candido Procopio Ferreira de. Kardecismo e umbanda. São Paulo, Pioneira, 1961.

CONCONE, Maria Helena Villas Boas e NEGRÃO, Lísias Nogueira. "Umbanda: da repressão à cooptação". Umbanda \& política. Cadernos do Iser, 18. Rio de Janeiro, Iser e Marco Zero, 1987.

MARIANO, Ricardo. Neopentecostais. São Paulo, Loyola, 1999.

Análise sociológica do crescimento pentecostal no Brasil. São Paulo, Departamento de Sociologia da Universidade de São Paulo, 2001.

NEGRÃO, Lísias Nogueira. Entre a cruz e a encruzilhada. São Paulo, Edusp, 1996.

ORO, Ari Pedro. "As religiões afro-brasileiras: religiões de exportação”. Em ORO, Ari Pedro (org.). As religiões afro-brasileiras no Cone Sul. Cadernos de Antropologia no 10. Porto Alegre, UFRGS, 1993.

PIERUCCI, Antônio Flávio. Magia. São Paulo, Publifolha, 2001.

PIERUCCI, Antônio Flávio e PRANDI, Reginaldo. A realidade social das religiões no Brasil. São Paulo, Hucitec, 1996.

PRANDI, Reginaldo. Os candomblés de São Paulo. São Paulo, Hucitec, 1991.

. Herdeiras do axé. São Paulo, Hucitec, 1996.

. Um sopro do Espírito. São Paulo, Edusp, 1997.

. Mitologia dos orixás. São Paulo, Companhia das Letras, 2000.

"Exu, de mensageiro a diabo: sincretismo católico e demonização do orixá Exu".

Revista USP, São Paulo, no 50, 2001 (a), pp. 46-65.

."Religião, biografia e conversão". Em BARBOSA, Dimas Lara (org.). O itinerário da fé, vol. 1. São Paulo, Paulus, 2001(b), pp. 51-76.

SOUZA, André Ricardo de. Padres cantores, missas dançantes. Dissertação de mestrado, São Paulo, Departamento de Sociologia da USP, 2001.

RESUMO - DESDE os estudos de Roger Bastide, na década de 1940, muita coisa mudou no Brasil, também no âmbito das religiões e das religiões afro-brasileiras. Velhas tendências foram confirmadas, novas direções foram se impondo. Religiões recém-criadas 
se enfrentam com as mais antigas, velhas religiões assumem novas formas e veiculam renovados conteúdos para enfrentar a concorrência mais acirrada no mercado religioso. Vou tratar aqui de um ramo religioso pequeno demograficamente, porém importante do ponto de vista de seu significado para a cultura brasileira e da visibilidade que transborda de seu universo de seguidores: as religiões afro-brasileiras. Trata-se de acompanhar as mudanças numéricas encontradas pelos censos para dimensionar os seguidores das religiões afro-brasileiras, e de examinar algumas de suas características, como cor e escolaridade, para então avançar, sem perder de vista as peculiaridades constitutivas e organizacionais dos cultos e terreiros, alguma explicação sobre mudanças pelas quais vêm passando essas religiões nos dias de hoje.

ABSTRACT - MUCH HAS changed in Brazil since the studies of Roger Bastide in the 1940s, including the religious milieu of the Afro-Brazilian religions. Old trends were confirmed, new directions imposed themselves. Newfangled religions confront the more established ones; old religions take on new forms and convey renewed contents to face increasingly strenuous_competition in the religious marketplace. I will deal here with a demographically small religious faction that is nevertheless important in Brazilian culture because of the visibility of its followers: the Afro-Brazilian religions. I will examine the various census figures in an attempt to assess the breadth of Afro-Brazilian religions and will examine some traits of their followers - such as race and educational level. Then, without losing sight of the constitutional and organizational peculiarities of the cults and the terreiros_[ritual grounds of the Candomble religion], I will attempt an explanation for the changes these religions are presently undergoing.

Reginaldo Prandi é professor do Departamento de Sociologia da Universidade de São Paulo e pesquisador do Conselho Nacional de Desenvolvimento Científico e Tecnológico (CNPq). Ocupa atualmente o cargo de representante da Área de Sociologia na Capes. É autor, entre outros livros, de Os candomblés de São Panlo (Hucitec, 1991), A realidade social das religiões no Brasil (com Antônio Flávio Pierucci, Hucitec, 1996), Herdeiras do axé (Hucitec, 1996), Um sopro do Espirito (Edusp, 1997), Mitologia dos orixás (Companhia das Letras, 2000), Encantaria brasileira (organizador, Pallas, 2001), Os príncipes do destino (Cosac \& Naify, 2001), Ifá, o Adivinho (Companhia das Letrinhas, 2002), Xangô, o Trovão (Companhia das Letrinhas, 2003) e Minha querida assombração (Companhia das Letrinhas, 2004).

Texto recebido e aceito para publicação em 8 de outubro de 2004. 